\title{
PROSPECTS OF USING NON-FRIED BUCKWHEAT GROATS IN FIRST DISHES TECHNOLOGY
}

\author{
Nataliia Yushchenko \\ Department of Restaurant Technology and Ayurvedic Products ${ }^{1}$ \\ YuNM_NUFT@ukr.net \\ Uliana Kuzmyk \\ Department of Milk and Dairy Product Technology \\ ukuzmik@gmail.com \\ Oksana Kochubei-Lytvynenko \\ Educational and Scientific Institute of Food Technologies ${ }^{1}$ \\ okolit@email.ua \\ Olha Yatsenko \\ Problem Research Laboratory ${ }^{l}$ \\ olga.yatsenko88@gmail.com \\ Tatiana Belemets \\ Department of Biotechnology and Microbiology \\ Tatiana_Belemets@i.ua \\ ${ }^{1}$ National University of Food Technologies \\ 68 Volodymyrska str., Kyiv, Ukraine, 01601
}

\begin{abstract}
It is urgent to develop a technology of cream-soups, allowing to widen possibilities of combining vegetable components and to give dishes with original taste-aromatic characteristics.

The main quality characteristic of soups-purees is a homogenous consistence. That is why for substantiating technological parameters of non-fried buckwheat groats preparation, an influence of boiling and preliminary soaking duration on structural-mechanical properties of the mixture has been studied. Rational technological parameters of non-fried buckwheat groats preparation have been determined: groats and water ratio $-1: 7$, preparation temperature $(90 \pm 2){ }^{\circ} \mathrm{C}$, process duration 15 min with preliminary hydration for 4 hours.

The effectiveness of using non-fried buckwheat groats in the composition of dishes in amount $8.0 \%$ has been proved, and spices compositions for first dishes have been developed: fragrant pepper, cumin, rosemary in ratio 1: 0.6: 0.4.

Keywords: buckwheat groats, cream-soup, first dishes, cereal, rheological properties, water-retaining capacity.
\end{abstract}

DOI: $10.21303 / 2504-5695.2020 .001542$

\section{Introduction}

First dishes are an obligatory component of the food ration of each human. They are a source of mineral and biologically active substances, contain essential amounts of liquids and cover the organism's need in water by $15-25 \%$ [1].

The popularity of first dishes is conditioned, first of all by their high food value because of the multicomponent composition: vegetables, cereals, lipids, animal meat or fish - traditional soup components. It must be noted, that soups have rather high assimilability level, conditioned by peculiarities of culinary processing of ingredients (frying, boiling, sometimes baking and so on) and enough liquid phase. Extractive nitrogen-containing and nitrogen-free compounds, organic acids, mineral compounds favor separation of digestive juices, heated product consumption also stimulates digestion and favors its better assimilability [2]. But for providing organoleptic parameters, soups are prepared on meat broths or with adding fat or cream butter that are reflected on their dietary properties. As opposite to traditional first dishes, soups-puree may be prepared on vegeta- 
ble broths, minimizing fat and using more vegetables, valuable in the aspect of healthy nutrients content, but their consumption is limited by taste preferences (for example, broccoli). So, widening the assortment of soups-puree, based on native raw materials, is a promising direction of scientific studies, allowing to improve the structure of population's nutrition.

Consumption quality estimation of first dishes is determined, first of all, by their taste parameters. Quantity introduction of one or other ingredients in the product content is often determined by their purpose: as a taste filler for partial replacement of a protein or carbohydrate component; as an aromatizer - for giving a tint of taste or smell.

Groats and groats products take $20 . . .30 \%$ of the total volume of grain products consumption in the nutrition structure of a modern human. Rice, buckwheat and oat groats and products of them are in the most demand among consumers [3].

The main component of cereal crops are carbohydrates, they are presented by starch, cellulose, humic substances. The total content of carbohydrate for cereals is over $65 \%$, leguminous over $50 \%$, of mainly starch, contained in seed endosperm as starch grains of different size and form [4]. Proteins are the most valuable component of a seed. Main proteins of a seed are albumins and globulins, buckwheat is especially rich. The content of proteins in different crops essentially varies from $7 \%$ (in rice) to $13 \%$ (in wheat). By amino acid composition, seed proteins are mainly full-value, because their composition contains all irreplaceable amino acids, including the most important ones - tryptophan, methionine and lysine [5].

Among cereals, buckwheat groats is remarkable because of the increased protein content $13.0-15.0 \%$. A peculiarity of buckwheat proteins comparing with ones of other cereals is practically complete absence of prolamines, low content of glutelins and high content of albumins (18.2\% of the protein mass) and globulins ( $43.3 \%$ of the protein mass). Buckwheat protein contains 18 amino acids, seeds are rich in arginine and lysine, protein biological value is $93.1 \%$ [6]. It is one of most full-value vegetable proteins, characterized by the high solubility and assimilability [7].

The total content of dietary fibers of buckwheat groats is 5-11\%, among them - cellulose, nonstarch polysaccharides, lignans. At that soluble cellulose is the main substance in buckwheat groats [8].

Buckwheat groats, subjected to hydrothermal processing - hydration with further steaming and drying, is mainly used in culinary. As a result, fruit capsules of buckwheat become more elastic, and a kernel - stronger. But at such processing, starch cleusterization takes place. Its amount depending on processing parameters decreases by $1.3 \ldots 2.8 \%$ at the expanse of complex creation with proteins, lipids and other seed components [9]. At that dextrins form, protein partially denatures and transforms in the insoluble condition (content of albumins decreases in 2.9, globulins - in 1.7 times). Groats gain the brown color and expressed typical smell [10].

Development and introduction of a technology of first dishes allow to involve a wider circle of consumers, caring about own health that favors further development of the public nutrition branch and population health improvement.

It is promising to develop a technology of cream-soups, allowing to widen possibilities of combining vegetable components and giving dishes original taste-aromatic characteristics.

\section{Materials and Methods}

For preparing model samples, the following raw materials were used: non-fried buckwheat groats by SSU 7697:2015 "Buckwheat groats. Technical conditions" (TM “Zhmenka"); kitchen salt by SSU 3583:2015 "Kitchen salt. General technical conditions”; broccoli by SSU 8147:2015 "Fresh broccoli. Technical conditions"; onion by SSU 3234-95 "Fresh onion. Technical conditions"; spices: aromatic pepper (TU U 10.8-01553439-006:2013 "Round aromatic pepper. Technical conditions" (TM "Mriya"), cumin (SSU ISO 6465:2003 "Whole cumin. Technical conditions" (ISO 6465:1984, IDT)), rosemary (SSU ISO 11164:2019 (ISO 11164:1995, IDT) “Dried rosemary. Technical conditions”); drinking water by SsanRaS 2.2.4-171-10 "Hygienic requirements to drinking water for human consumption".

The spices for introducing in the composition of a dish were comminuted to particles sizes no more $2 \mathrm{~mm}$ by a mill for salt and pepper Lamart.

For determining the aromatic profile of the spice composition and organoleptic estimation of model systems for first dishes, the model method was used by SSU ISO 6564:2005 "Sensor study. 
Methodology. Methods of flavor creation". Its essence is in dividing the sensor parameter - smell in simple components. The method of profile analysis provides two main stages: choice of descriptors and constructions of the product profile. At choosing descriptors (panel of descriptors), the main attention is paid to specific tints and notes.

For constructing the product profile, the tasting commission of the authors of this work offered to estimate values of the chosen descriptors by the 5-point scale: 1 - non-expressed smell; 2 - weakly expressed smell; 3 - moderate smell; 4 - desired smell; 5 - excessively expressed smell, not inherent to products.

At studying the taste and smell of spice compositions by the profiling method, the following descriptors were taken into account: spice-sweat, camphor, lemon, herbal, astringent, bitter, pungent, spicy, salty.

Based on tasting commission's conclusions, the ponderability coefficient for each descriptor was determined by the "method of fixed sum", according to which the sum of ponderability coefficients for all separated quality parameters must equal the preliminarily determined number:

$$
\sum_{i=1}^{n}=\text { const. }
$$

In our case:

$$
\sum_{i=1}^{12}=1
$$

The complex index by smell and taste was calculated by the formula:

$$
R=M_{i} \cdot D
$$

where $R$ - complex index of smell and taste; $D$ - average point mark by each descriptor; $M_{i}-$ ponderability coefficient of each sign.

The water-retaining capacity was determined by the centrifuging method. At that samples of $4 \mathrm{~g}$ were placed in centrifugal test-tubes and centrifuged at $1500 \mathrm{rot} / \mathrm{min}$ [11].

The active acidity was determined potentiometrically at the universal ionometer EV-74 by SS 26781-85.

Rheological properties were determined on the rotation viscosimeter «Rheotest II» with the measuring system cylinder-cylinder $S / N$ by fixing curves of deformation kinetics (flow).

The measurements were conducted at temperature $20^{\circ} \mathrm{C}$. The measuring cylinder (rotor) $N$ was chosen for providing a gradient layer spreading by the whole thickness of the layer of the product, placed in the ring air gap of the measuring device of the viscosimeter. The shear stress $\theta(\mathrm{Pa})$ was measured by 12 values of the shear speed gradient $\gamma$ in the diapason from 0 to $100 \mathrm{~s}^{-1}$ at direct and reverse running. For that, $\alpha$ indices were fixed at the maximal deviation edge of an indicator on the device scale [12].

The shear stress $(\mathrm{Pa})$ was calculated by the formula:

$$
\theta=Z \cdot \alpha
$$

where $Z$ - cylinder constant, Pa un. of the scale; $\alpha$ - measuring indicator of the device scale.

The production technological process of first dishes consists of the following operations: preparation of raw materials for production; preparation of puree; preparation of non-fried buckwheat groats; mixing of recipe components and boiling; ready dish.

The obtained results of the measurements and the graphic presentation of the experimental data needed standard programs for statistical processing Microsoft Excel 2010. The distinctness of the obtained results was provided by three-fivefold iteration of the experiments.

\section{Results}

The main quality characteristic of soups-puree is a homogenous consistence, obtained by the special equipment, adding the mixture of egg yolks, milk, four, cream and so on in the commi- 
nuted mass. The structure of soups-puree mainly depends on stabilizers, stiffeners with limited use terms and certain technological defects. But there is no necessity in stiffeners for puree-like products with non-fried buckwheat groats, because it contains starch, dietary fibers and slime, favoring system's stabilization against stratification.

For the rational use of non-fried buckwheat groats, at the first stage of the work the optimal ratio between groats and water was determined. For that, the model samples were prepared with a ratio from 1:1 to 1:8. Sample No. 1 - ratio between buckwheat groats and water 1:1; sample No. 2 - ratio between buckwheat groats and water 1:2; sample No. 3 - ratio between buckwheat groats and water 1:3; sample No. 4 - ratio between buckwheat groats and water 1:4; sample No. 5 - ratio between buckwheat groats and water 1:5; sample No. 6 - ratio between buckwheat groats and water 1:6; sample No. 7 - ratio between buckwheat groats and water 1:7; sample No. 8 - ratio between buckwheat groats and water 1:8.

Buckwheat groats was mixed with water and heated to temperature $(90 \pm 2){ }^{\circ} \mathrm{C}$ with process duration $(30 \pm 5) \mathrm{min}$. The obtained buckwheat mixture was cooled to temperature $(20 \pm 2)^{\circ} \mathrm{C}$ and structural-mechanical properties were studied. The obtained results are presented on Fig. 1.

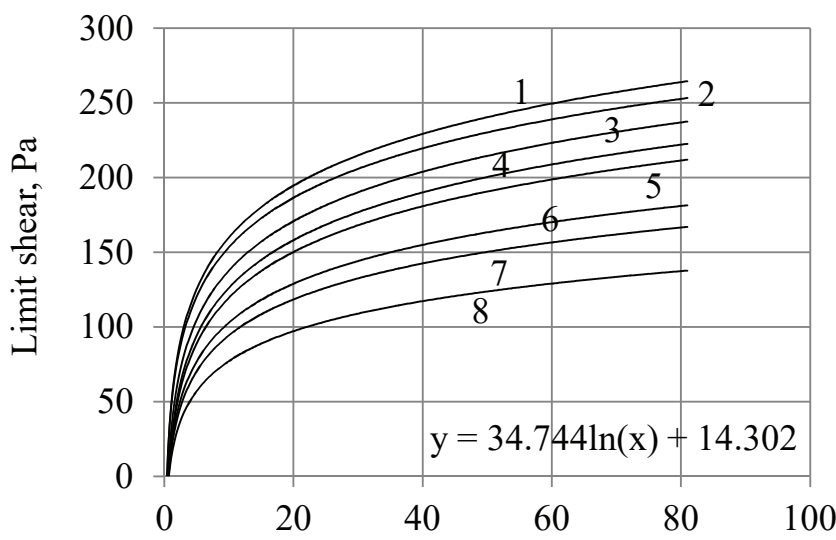

Deformation speed, $1 / \mathrm{s}$

Fig. 1. Dependence of stress gradient on deformation speed of the model samples at different buckwheat groats and water ratios

It has been experimentally established, that the rational proportion of groats and water is 1:7. At a less water content, the mixture consistence is dense and loses its fluidity. At higher ratio 1:8 - the consistence is liquid because of excessive water. The stress gradient at different ratios between water and groats is within 100-300 Pa that corresponds to viscous-plastic systems with a normal consistence.

It has been established, that the active acidity of the buckwheat mixture didn't change depending on components' ratio and was $6.2 \mathrm{pH}$ un.

For substantiating technological parameters of non-fried buckwheat groats preparation, an influence of boiling and preliminary soaking duration on structural-mechanical properties of the mixture was studied (Fig. 2).

For that, the model samples were prepared at the ratio non-fried buckwheat groats : water as 1:7. Buckwheat groats was mixed with water, heated to temperature $(90 \pm 2){ }^{\circ} \mathrm{C}$. The process duration for different samples was 10, 15, 20, $30 \mathrm{~min}$. The obtained buckwheat mixture was cooled to temperature $(20 \pm 2){ }^{\circ} \mathrm{C}$. For determining the influence of long hydration on structural-mechanical properties of the model systems, after mixing groats with water, it was kept during 4 hours at temperature $(6 \pm 2){ }^{\circ} \mathrm{C}$, then processed by temperature by the aforesaid method.

The highest water-retaining capacity index was observed in the sample with processing duration 15 min and keeping during 4 hours $-65.0 \%$. In the sample with groats processing duration $30 \mathrm{~min}$ and keeping during 4 hours the water-retaining capacity increased only by $3.0 \%$.

The highest shear stress index as $178 \mathrm{~Pa}$ was observed in the sample with processing duration 30 min without long hydration (Fig. 3). 


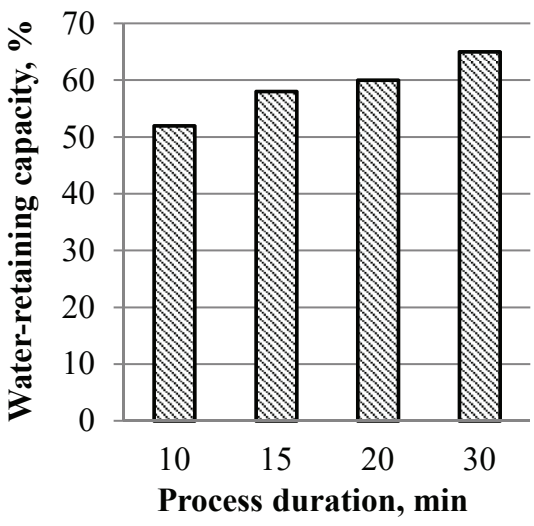

$a$

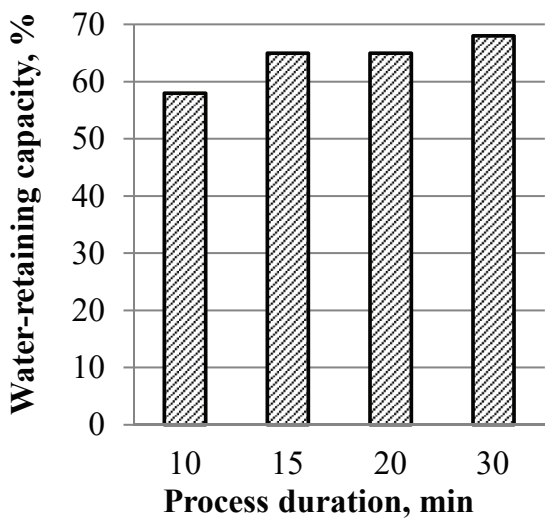

$b$

Fig. 2. Influence of boiling duration of the buckwheat mixture on water-retaining capacity index: $a$ - without long hydration; $b$ - with long hydration

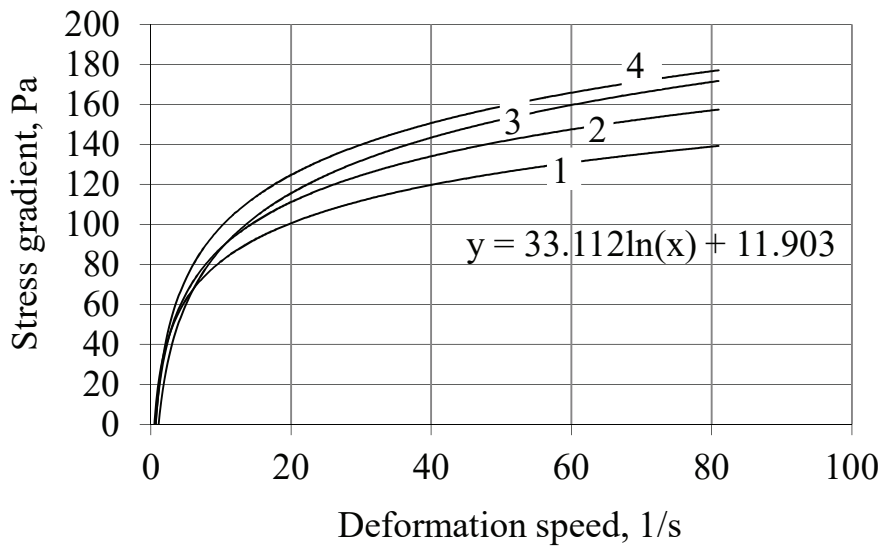

Sample, No.

$\begin{array}{ll}1 & \text { Temperature processing duration } 10 \mathrm{~min} \\ 2 & \text { Temperature processing duration } 15 \mathrm{~min} \\ 3 & \text { Temperature processing duration } 20 \mathrm{~min} \\ 4 & \text { Temperature processing duration } 30 \mathrm{~min}\end{array}$

Fig. 3. Dependence of stress gradient on deformation speed of the model samples with different processing duration of the mixture

Thus, the rational technological parameters of non-fried buckwheat groats preparation were determined: groats and water ratio $-1: 7$, preparation temperature $(90 \pm 2){ }^{\circ} \mathrm{C}$, process duration 15 min with preliminary hydration 4 hours.

The organoleptic estimation results of the model samples with different amounts of the buckwheat mixture are presented as profilograms (Fig. 4). For constructing the product's profile, there were chosen values of descriptors, estimated by the 10-point scale. Based on the organoleptic estimation, it has been established, that non-fried buckwheat groats is compatible with other ingredients in the composition of a dish. The color of the samples with buckwheat groats is creamy, consistence is homogenous.

The dependence of the water-retaining capacity index of the buckwheat mixture on its introduction amount (Fig. 5).

It has been established, that the best water-retaining capacity index is in the sample with $10.0 \%$ of buckwheat groats. With the mass share of groats from $2.0 \%$ to $8.0 \%$, the water-retaining capacity index increased by $16 \%$, whereas with the dosage increase from $8.0 \%$ to $10.0 \%-$ by $2.0 \%$.

Based on the analysis of spices' properties, aromatic pepper, cumin and rosemary were chosen for the composition. The ratio of separate components in the composition was determined based on the organoleptic estimation of the model samples of combination spice mixtures, introduced in the prepared 
base. The separate spices were introduced to the recipe composition in basic amounts, taking into account their drying properties. Based on preliminary studies, it has been established, that the moderately expressed taste of these spices is observed at the following amounts: aromatic pepper $-0.5 \ldots 0.7 \%$ (in average $0.6 \%$ ), cumin $-0.2 \ldots 0.6 \%$ (in average $0.4 \%$ ); and rosemary $-0.2 \ldots 0.4 \%$ (in average $0.3 \%$ ).

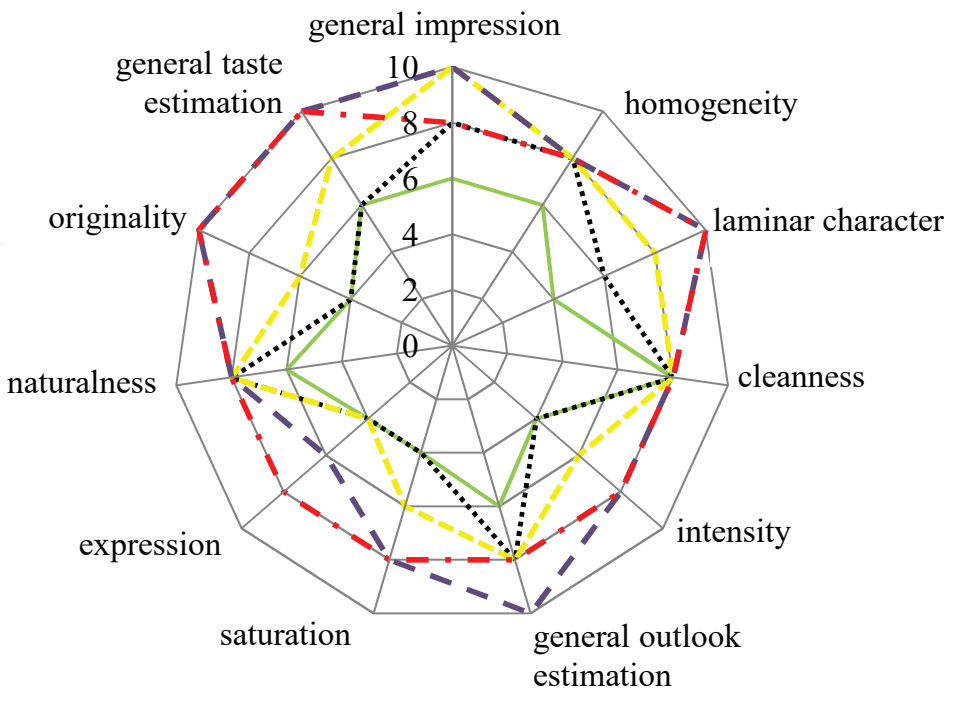

groats introduction amount, \%

$\square 2: 4: 6 \llbracket 8 \llbracket 10$

Fig. 4. Profilogram of the organoleptic estimation of the model systems for first dishes at different amount of non-fried buckwheat

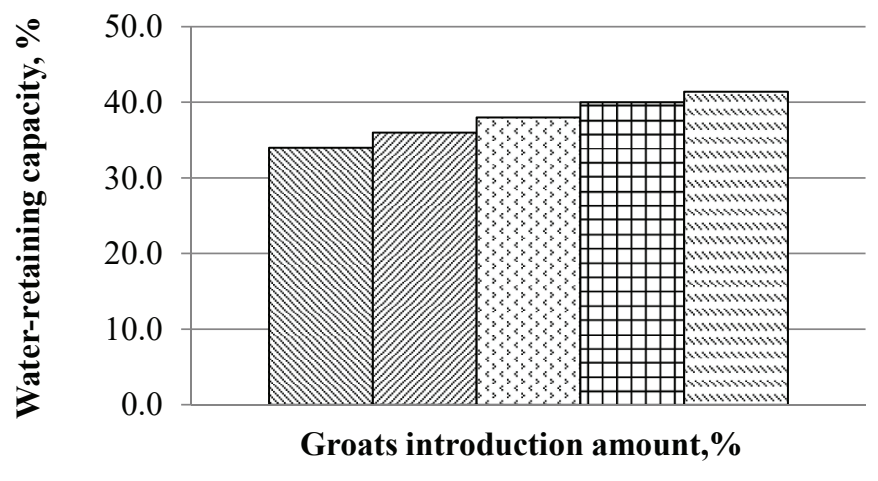

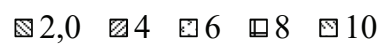

Fig. 5. Dependence of water-retaining capacity on the mass share of buckwheat groats

The component ratio in the composition by basic values is aromatic pepper:cumin:rosemary $=0.6: 0.4: 0.3$ or $1: 0.7: 0.5$.

For determining the rational component ratio in the combination, it was changed from 1 : 0.4: 0.2 to $1: 0.8: 0.6$.

Taste-aromatic properties of the model samples were estimated by the 5-point desirability scale: 5 - very desirable; 4 - desirable; 3 - insufficiently desirable; 2 - not very desirable; 1 - undesirable; 0 - inadmissible. The profilogram of taste and smell of the model samples at different spice ratios is presented on Fig. 6.

Analyzing the taste and smell profilogram of the model samples of first dishes at different amounts of rosemary, we can make a conclusion that the rational proportion of aromatic pepper: cumin: rosemary at equal amounts of rosemary is $1: 0.5: 0.4$. At such ratio the model samples have the best mark by both taste and smell. 


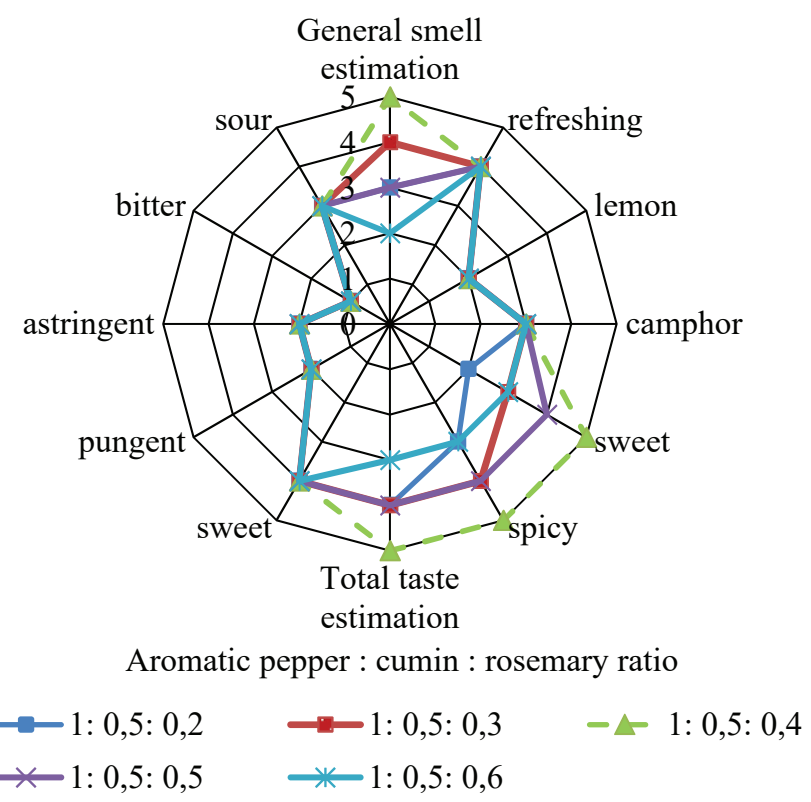

Fig. 6. Taste and smell profilogram of the model samples with the spices at different rosemary amounts

At the following stage the dish model samples were prepared at different cumin amounts. The obtained data are presented in Fig. 7. Analyzing the taste and smell profilogram of the model samples with the spices at different amounts of cumin, we can make a conclusion that the rational proportion of aromatic pepper: cumin: rosemary at equal amounts of cumin is 1: 0.6: 0.4 . At such ratio the samples have the best mark by both taste and smell.

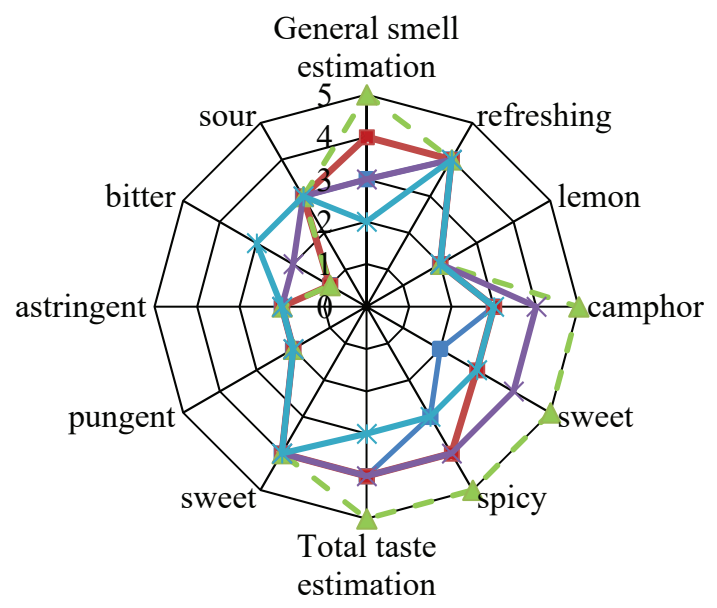

Aromatic pepper : cumin : rosemary ratio

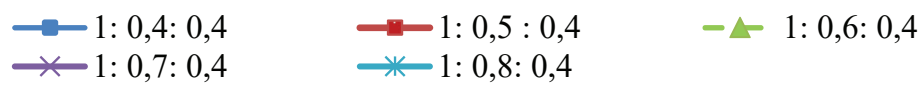

Fig. 7. Taste and smell profilogram of the model samples with the spices at different cumin amounts

For determining the rational amount of introduction of the spice composition in first dishes, the model samples were prepared with the introduction amount of the developed composition from 0.3 to $1.0 \%$ with interval $0.1 \%$.

The model samples had the moderately expressed taste and smell at introducing the developed spice composition as $0.5 \%$. With the amount increase, taste and smell became more expressed that is not desirable. 


\section{Conclusions}

According to the research results, the use of non-fried buckwheat groats in the cream-soup technology has been substantiated.

The expedience of preliminary hydration of non-fried buckwheat groats has been proved. Rational technological parameters of non-fried buckwheat groats preparation have been determined: groats and water ratio $-1: 7$, processing $(90 \pm 2){ }^{\circ} \mathrm{C}$, process duration $15 \mathrm{~min}$ with preliminary hydration for 4 hours at temperature $(20 \pm 2){ }^{\circ} \mathrm{C}$.

The effectiveness of using non-fried buckwheat groats in the composition of dishes in amount $8.0 \%$ has been proved. The rational amounts of spice compositions introduction in first dishes as $0.5 \%$ in ratio 1: 0.6: 0.4 have been determined.

\section{References}

[1] Moskalenko, V. F., Hruzieva, T. S., Halienko, L. I. (2009). Osoblyvosti kharchuvannia naselennia Ukrainy ta yikh vplyv na zdorovia. Naukovyi visnyk Natsionalnoho medychnoho universytetu im. O. O. Bohomoltsia, 3, 64-72.

[2] Izo, O. V. (2016). Using modern equipment (herbofiltriv) in the preparation of the first ukrainian dishes. Materials of V International scientific and technical conference of young researchers and students "Actual problems of modern technologies". Vol. II. Ternopil, 231.

[3] Sots, S. M., Kustov, I. O. (2013). Perspektyvni napriamky rozvytku haluzi krupianykh produktiv. Zernovi produkty i kombikormy, 4 (52), 18-20.

[4] Hryhorenko, O. M. (2013). Rozrobka produktiv kharchuvannia, zbahachenykh mikroelementamy, yak zasib vyrishennia problemy hiper- i hipomikroelementoziv. Visnyk Donetskoho natsionalnoho universytetu ekonomiky i torhivli im. M. Tuhan-Baranovskoho. Ser.: Tekhnichni nauky, 1 (57), 33-41.

[5] Kurzun, V. N. (2009). Teoretychni osnovy stvorennia ta vzhyvannia produktiv spetsialnoho pryznachennia. Dovkillia ta zdorovia, 1, 63-68.

[6] Grechka zelenaya. Available at: http:/grechka-zelenaya.ru/ogrechke-zelenoj/grechka-zelenaja-sport-syroedenie/grechka-zelenaja.html

[7] Zhang, L. (2009). Functional Characteristics of Traditional buckwheat products. Journal of Chinese Cereals and Oils Association, 24 (3), 53-57.

[8] Liu, C.-L., Chen, Y.-S., Yang, J.-H., Chiang, B.-H. (2008). Antioxidant Activity of Tartary ( Fagopyrum tataricum (L.) Gaertn.) and Common (Fagopyrum esculentum Moench) Buckwheat Sprouts. Journal of Agricultural and Food Chemistry, 56 (1), 173-178. doi: https://doi.org/10.1021/jf072347s

[9] Dubinina, A., Popova, T., Lenert, S. (2014). The vitamin and mineral content of buckwheat groats. Tovary i rynky, 2, $106-115$.

[10] Yushchenko, N. M., Mykoliv, I. M., Kuzmyk, U. H. (2015). Vykorystannia nesmazhenoho zerna hrechky v retsepturakh kyslomolochnykh produktiv. Visnyk Kharkivskoho Natsionalnoho Tekhnichnoho Universytetu silskoho hospodarstva im. Petra Vasylenka, 166, 69-75.

[11] Krainiuk, L. M. (Ed.) (2012). Metody kontroliu yakosti kharchovoi produktsiyi. Sumy: Universytetska knyha, 512.

[12] Pasichnyi, V., Yushchenko, N., Mykoliv, I., Kuzmyk, U. (2015). Structure Stabilization of Fermented-Milk Pastes. Ukrainian Food Journal, 4, 431-439. 